\title{
THE MALUKU WARS: BRINGING SOCIETY BACK IN
}

Gerry van Klinken ${ }^{\top}$

\section{Introduction}

Throughout the Suharto era, political scientists found Latin American corporatist models of the all-pervasive state among their most useful tools. But the Maluku conflict forces us to reexamine these long-held convictions about the Indonesian state and its relations with society. Today nobody talks corporatism, and observers are looking for other heuristic aids to help explain violence in Indonesia. Perhaps we should be looking at Africa's failed states. According to a comprehensive study of communal conflict around the world conducted by Ted Gurr and his colleagues, 42 percent of sub-Saharan Africans belong to a politicized communal group. Their leaders manipulate ethnicity not in order to break away from the state but to grab a bigger share of state power for themselves. Gurr labels this kind of conflict the "communal contenders" conflict. ${ }^{2}$

\footnotetext{
${ }^{1}$ Editor, Inside Indonesia magazine (editor@insideindonesia.org). I am especially grateful to Smith Alhadar, Richard Leirissa, and Tamrin Amal Tomagola in Jakarta; to PM Laksono, Arifah Rahmawati, and Lambang Trijono in Yogyakarta; to Yusuf Halil, Dur Kaplale, John Mailoa, Lutfy Sanaki, Malik Selang, and Abdullah Soulissa in Ambon, and to all the members of Yayasan Baileo in Ambon. Lance Castles provided valuable statistics as well as critical feedback. Further constructive criticism came from Ed Aspinall, Nils Bubandt, Jamie Davidson, Stefan Eklof, Dwight King, Mochtar Mas'oed, Nico Schulte Nordholt, Richard Tanter (at great length), as well as Benedict R. O'G. Anderson. Inside Indonesia helped with some travel costs. This paper was essentially finished by May 2000 and does not deal with the renewed fighting in June 2000.

2 Ted Robert Gurr, Minorities at Risk: A Global View of Ethnopolitical Conflicts (Washington DC: US Institute of Peace Press, 1993). The other categories are ethnonationalists, indigenous peoples, ethnoclasses, and militant (religious) sects. On communal contenders, a topic which concerns culturally distinct groups within a heterogeneous society, see James R. Scarritt about sub-Saharan Africa, "Communal Conflict and Contention for Power in Africa South of the Sahara," in Gurr, Minorities at Risk, pp. 252-89.
} 
A perspective framed by the "communal contenders" analysis assumes an instrumentalist view of ethnicity rather than a primordialist one. ${ }^{3}$ This paper argues that the Maluku religious violence can best be seen as the result of an interaction between long-term "primordialist" social patterns and a short-term instrumentalization of those patterns in the context of intra-elite competition at the local level, a competition that fits the "communal contenders" frame. Religious passions were mobilized at certain precise times (elections, the inauguration of a new province) and in certain exact locations (within the bounds of Maluku province). Elites were able to do the mobilizing largely because society in Maluku was hierarchically structured into competing religious segments.

Clientelist models of politics in Indonesia have a long history, and their importance becomes apparent once more today. They emphasize the centrality not of impersonal institutions, but of personal ties of obligation between the individual government leader and the influentials they appoint to positions of power within the state machinery, thus creating a hierarchical, behind-the-scenes network of ties that can stretch from the capital to the remotest provincial town. Highlighting the role of patronage networks at the provincial level helps move the analytical focus away from Jakarta-centric concepts of a highly centralized state to more disaggregated ones. ${ }^{4}$ The unstable nature of these networks in a moment of regime transition provides, in this analysis, the key to understanding Maluku's wars. There are clearly global aspects to the reduced ability of the central state to maintain enough institutional coherence to impose its will in Maluku, but these fall outside the scope of the present paper.

\section{The Story in a Nutshell}

\section{The Human Cost}

We need to use the plural "wars" when referring to recent conflicts in Maluku because there were a great number of violent incidents. They can be broadly grouped into Ambon-related fighting in the south of Maluku province from January 1999 onwards, and North Maluku fighting following the establishment of a new province there in the second half of 1999.

Estimates of casualties and internally displaced people from the Maluku wars of 1999-2000 are very sketchy. By September 1999, before North Maluku had assumed serious proportions, the Jakarta-based humanitarian and human rights organization, Kontras, estimated that 1,349 had died because of inter-communal violence and repressive action by security forces since January 19, 1999. The North Maluku conflict was bloodier than that centered on Ambon. The North Maluku provincial government said that, between October 1999 and March 20, 2000, 2,004 had died, 1,769 had been injured, and 2,315 had disappeared or run away into the jungle. These figures were

\footnotetext{
3 The distinction is discussed inter alia in David Brown, The State and Ethnic Politics in Southeast Asia (London and New York: Routledge, 1994).

4 See Guenther Roth, "Personal Rulership, Patrimonialism and Empire Building in the New States," World Politics (January 1968): 194-206; S. N. Eisenstadt, Traditional Patrimonialism and Modern Neopatrimonialism (Beverly Hills, CA: Sage Publications, 1973). On the need to "disaggregate" Third World states, see Joel Migdal's introduction to Joel S. Migdal, Aful Kohli, and Vivienne Shue, eds., State Power and Social Forces (Cambridge: Cambridge University Press, 1994).
} 
consistent with other published estimates. Calculating fatalities from the entire Maluku conflict, the Catholic Bishop of Ambon estimated a figure of three to four thousand deaths by early 2000, with more than half of those occurring in just a few days in North Maluku, and he was perhaps not far off the mark.

Death and destruction on this scale had not been seen in Maluku since World War II. These mortality figures are larger than those estimated to have occurred in Aceh over a similar period at the height of the 1989-92 rebellion, and larger than those incurred in the West Kalimantan unrest of 1997, which (apart from the East Timor invasion) were the worst cases of collective violence since Indonesia's 1965-1966 bloodbath.

Meanwhile, the number of persons internally displaced due to the conflict was put at between 123,000 and $370,000.5$ These figures are comparable to the number displaced by the East Timor crisis in late 1999, which received overwhelming world attention.

\section{Ambon}

The state rigidly distinguishes five religions in Indonesia, including Protestants, who in Indonesia are called "Christians" (Kristen), at 11 percent, and Catholics (Katolik), at 4 percent. Every religion is widely considered incompatible with every other. In this paper the word "Christian" is used in its Western sense to refer to both Protestants and Catholics. In the main, the Maluku wars involved conflicts between Muslims and Protestants.

Violence between majority Muslims (officially 88 percent in 1982) and minority Christians has been rare in Indonesian history. When it did occur, it was usually a side effect of anger against (often Christian) Chinese shopkeepers. But the end of the New Order was marked by an increasing number of Muslim-Christian incidents. On October 10, 1996, all the churches in Situbondo, East Java, both Protestant and Catholic, were destroyed or damaged in the space of a few hours. On November 22, 1998, fighting broke out between Protestants and Muslims in Ketapang, central Jakarta, in which fourteen were killed and twenty-seven Christian buildings damaged. On November 30, 1998, a demonstration in sympathy with Protestant victims of Ketapang turned into an anti-Muslim riot that damaged or destroyed fifteen mosques and many shops in Kupang. The latter two incidents were much discussed around eastern Indonesia, where Christians outnumber Muslims in some localities. Several disturbing confrontations also took place within Maluku-the biggest was a riot that occurred in Dobo, Southeast Maluku, on January 14, 1999, leaving eight dead.

On January 19, 1999, fighting broke out between gangs of young men in the Batumerah transport terminal in the heart of Ambon city, the hub and capital of Maluku province. ${ }^{6}$ It was the holiest day in the Islamic calendar, Idul Fitri. Unlike previous fights in the transport terminal, this disturbance soon spread throughout the

${ }^{5}$ Government of the Republic of Indonesia and International Agencies, The Maluku Crisis: Report of the Joint Assessment Mission (Jakarta: GOI, February 6, 2000), pp. 8, 17.

${ }^{6}$ Human Rights Watch Asia, "The Violence in Ambon," www.hrw.org/hrw/reports/1999/ambon/, March 1999. 
city, especially in lower-class areas. At first it tended to be defined (especially by Protestant Ambonese) as an attack by "indigenous" Ambonese against non-Ambonese "newcomers" who happened to be Muslim. But it quickly acquired a purely religious, rather than ethnic or geographic, character and developed into a fight pitting Muslims against Protestants.

Fire was a major weapon, as homes and houses of worship belonging to adherents of a minority religion in any particular area were torched by the hundreds. Child fighters aged seven to twelve, known as agas (after a jungle mosquito), were held in awe by both sides because of their purported magical powers, including invulnerability. They were given jerry cans of petrol and used as arson squads, backed by men with machetes or homemade guns.

Fighting broke out in many places around the southern part of the archipelagic province of Maluku after the Idul Fitri event: in the islands of Seram, Buru, Sanana, Manipa, and Tanimbar. Sketchy reports in the national press gave the impression that telephonic communication with relatives in Ambon rapidly heightened anxieties in the regions. This in turn triggered violence between young men from neighboring villages. Sometimes local elites-village heads, district heads-were named as direct protagonists in the violence.

More violence broke out in Tual, capital of the regency (kabupaten) of East Southeast Maluku, where Catholicism has the most adherents, on another date with religious significance. The date, March 31, 1999, fell three days after the Muslim Idul Adha festival and two days before Christian Good Friday. Vicious fighting soon left hundreds dead and tens of thousands displaced from their homes; these disturbances broke out between neighboring villages, but were spoken of as Protestant (Kristen) versus Muslim conflicts. Lesser incidents occurred in many other villages around the far-flung regency.

On July 24, serious fighting broke out in Ambon city's middle-class suburb of Poka. Ignoring the many smaller incidents that had occurred after the Idul Fitri event (including the expulsion of all Christians from the beautiful Banda Islands in late April), Ambonese called this the Second Riot. It soon spread back to the center of Ambon city. The largely Chinese-owned business district along A. J. Patty Street was devastated. As in January, militants attempted without success to reach the symbolic heart of the enemy side-the Al Fatah mosque and the Maranatha Protestant church, respectively, separated in space by just three hundred meters but in the imagination by a yawning gulf of hatred. The second riot proved more shocking than the first to members of the more educated middle class, who told me it destroyed the optimism they had held till then that reconciliation remained possible. While Catholics in Ambon were considered non-partisan during earlier violent episodes and therefore shielded from attack, their churches too became Muslim targets during the second riot.

The Third Riot in Ambon once more took place during a religious holiday seasonon December 26, 1999, the day after Christmas. Despite the presence of a large number of troops that had been in Ambon since early in the conflict to separate the warring sides, one of Ambon city's main Protestant churches, Silo, was burned down, perhaps more by accident than design. The next day the An-Nur mosque was burned down. 
Within five days, seventy people were reported dead. The Fourth Riot took place in June 2000 and again killed about fifty people.

Whereas in January 1999 no one outside the police and armed forces had modern firearms and only a few used primitive homemade guns, by December both sides had acquired semi-automatic rifles from sources that remained largely mysterious, and clandestine workshops were producing sophisticated rifles that used military-style ammunition. Homemade bombs were in abundant supply.

The legacy of this violence was a society far more deeply segregated than it had ever been before. One report written after the second riot estimated that "white" (Muslim) forces controlled approximately 40 percent of Ambon city while "red" (Protestant) fighters controlled 60 percent. This ratio roughly reflected the religious division of Ambon city's population, so all the blood that had been shed had not bought either side an increase in territory. Subsequent fighting probably did not move borders substantially, but did eliminate most enclaves. Ambon and surrounding islands (Haruku, Saparua, Seram) were segregated into white and red areas, while heavily armed soldiers guarded the crossover points. In Tual, reports indicated a degree of mixing and interaction between Muslims and Protestants following an easing of tension by the end of 1999. Perhaps the Catholics, who were not involved in the Muslim-Protestant fighting, had had a moderating influence there.

Ambon's economy lay in ruins. The once-busy main harbor, as well as many smaller harbors, was deserted. People felt safe to travel only within "their" territory. Even inter-island shipping was segregated-Muslims traveled to Ambon on the Pelni line via Makassar and disembarked at the harbor, while Christians traveled on the Pelni line via Kupang and disembarked at the naval base. The arrangement developed after a number of passengers were stabbed to death and their bodies dumped overboard.

\section{North Maluku}

The North Maluku conflict was more bloody than that in Ambon, yet it received far less coverage in the national press. One reason for the dearth of publicity was the area's remoteness and lack of infrastructure: Ternate has no local newspaper and no university. Another was a degree of conflict fatigue that had dulled the interest of the national press by the time North Maluku erupted. My emphasis on Ambon rather than North Maluku in the present account is largely a result of these constraints (as well as of the need for brevity), since my analysis relies on a close critical reading of the Indonesian press reports. However, the argument in favor of local causes for the violence hopefully does not need to be repeated in detail for both areas.

North Maluku initially remained largely free of conflict. But during August 18-20, 1999, fighting broke out between neighboring villages at Kao and Malifut on the western side of Kao Bay on Halmahera's northern peninsula.7 The quarrel concerned a

\footnotetext{
7 Tamrin Amal Tomagola, "Tragedi Maluku Utara," Majalah Masyarakat LIPI 25,2 (1999); Smith Alhadar, "The Forgotten War in North Maluku," Inside Indonesia 63 (July-September 2000): 15-16.
} 
6 Gerry van Klinken

government plan announced late in June 1999 to create a new governmental district (kecamatan) in Malifut, a plan Kao leaders rejected.

The Kao, Jailolo, and Tobelo people who inhabited the villages near Kao are indigenous to this peninsula, and they say they are traditionally "allied" to the Sultan of Ternate. They are also mostly Protestant. The inhabitants of Malifut, meanwhile, were transmigrants from Makian Island south of Ternate. They were moved here after government scientists in 1975 predicted that a tremendous volcanic explosion on Makian would follow an observed smaller one. The eruption never came, and the Makian were left to their own devices in Malifut.

Makian are apparently well represented in the provincial bureaucracy; they are Muslim, and they do not have the same affection for the Sultan of Ternate. North Maluku Protestant elites always suspected that the government decision to transmigrate the Makian to Malifut in the 1970s had been "political"- to stop the southward expansion of Protestant Christianity into territory traditionally "controlled" by the sultanate of Tidore, Ternate's near neighbor and long-standing rival.

To make matters more explosive, an Australian-discovered gold mine had started operations in mid-1999 in Kao territory, and many Kao suspected the Makian of wanting to control local revenue and employment in the mine by incorporating it into their new district.

Moreover, by August 1999 it seemed certain that North Maluku would become a province in its own right-in response to a long-standing demand from North Malukan elites. The change heightened tensions among these same elites who were in competition for the spoils of office. These tensions crystallized around the sultanates of Ternate and Tidore, traditional institutions officially recognized only as "customary leaders," but evidently still capable of attracting considerable loyalty despite a century of "modern" government in North Maluku. For them, control over territory was the key to strategic success.

The August 1999 incident left several dead on each side and hundreds of houses burned down. Makian refugees trickled into Ternate and Tidore. The issue then lay dormant until it exploded again on October 24, 1999. Those on the Kao side quickly won the upper hand. As a result, the entire Makian settlement was burned to the ground. All eight thousand Makian who lived there became refugees. On their way to their own island of Makian, they spent time in (southern) Ternate as well as in Tidore. There their stories of woe fueled anger against Christians of any sort, anger that had already been inflamed by the year's events in Ambon.

Beginning in Tidore on November 3, violence forced all the Christians to take refuge in police headquarters before they were escorted out of Maluku to largely Protestant Minahasa in North Sulawesi by navy ships or commercial aircraft. A minister was killed, as were several other Protestants, while church buildings and many houses were burned. Christians in Ternate fled to safe houses in northern Ternate that were provided by the Sultan of Ternate, before they too were evacuated to North Sulawesi. Their number in North Sulawesi eventually reached thirteen thousand (one report says 22,800 ). Many were civil servants or private businessmen. Only 30 percent of the city's 
teachers were left in Ternate, a city that needed even more teachers than normal to cope with the influx of Muslim refugees.

On December 27, Protestant Christians in Tobelo, the second area of local Protestant dominance besides Kao, attacked several Muslim transmigration villages in the nearby district of Galela and massacred between four hundred and five hundred people-mostly women and children-in two mosques. It was the worst single massacre in the Maluku wars. ${ }^{8}$ Reports of the massacre enormously strengthened the determination of militant Islamic groups in Ternate, as well as in Java, to wreak vengeance on Protestants remaining in North Halmahera. Very sketchy reports between January and up until the time of writing (May 2000) describe ongoing fighting in many places in the peninsula.

Again, local elites were directly implicated in the violence. The sultans of Ternate and of Tidore each controlled "traditional troops" (pasukan adat), essentially private armies that they brought into play at crucial moments when they instead should have called on the state apparatus to restore order. Indeed, there were indications that a political defeat suffered by the Sultan of Ternate in December 1999, after which he retired to Jakarta, signaled the end of the strategic phase of fighting. The many incidents of 2000 could perhaps be seen as revenge attacks that took place in the aftermath of the explosive violence; these "after-shocks" served no one's real interests and gradually declined in intensity.

\section{Why Jakarta Didn't Do It}

The view that Jakarta elites were responsible for the Ambon tragedy was widespread, especially in its first weeks. An unreformed military, presumably financed by Suharto and his Golkar and "crony" old guard, was most often cited as the provokator par excellence. The assumption was that military intelligence intended to destabilize the newly democratic governments in Jakarta (that of Habibie, and, after October 1999, that of Abdurrahman Wahid) and thus hasten the return of military dominance.

In the nature of the case, evidence for an intelligence operation in Ambon was difficult to come by, but names were occasionally mentioned. Locally born Brig-Gen (retired) Rustam Kastor, former garrison commander in Maluku, was closely associated with militant Muslims in Ambon and published an angry book about the injustices committed by Ambonese Protestant Christians. ${ }^{9} \mathrm{He}$ was supposed to have had contact with a group of disgruntled army officers under Maj-Gen Kivlan Zein in Jakarta, who was evidently somewhat of a dirty tricks specialist. Militant Protestants also had a champion in the armed forces in the person of Lt-Gen (retired) Leo Lopulisa.

However, these were Ambonese actors trying to influence Jakarta, rather than the reverse. Indeed, the military provocateur theorists who wagged their heads at the

8 "Indonesia Island Buries Hundreds of Killing Victims," Reuters, January 10, 2000.

${ }^{9}$ Rustam Kastor, Konspirasi Politik RMS dan Kristen Menghancurkan ummat Islam di Ambon-Maluku (Yogyakarta: Wihdah, February 2000). 
"sophistication" of the Jakarta intelligence operation for its ability to exploit preexisting tensions became less and less convincing as time went on. Jakarta intelligence does not have a record of local sensitivity. It is difficult to imagine that an armed forces strapped for cash, still laboring under a public relations nightmare in East Timor, and facing separatist revolts in Papua and Aceh, would have resources to invest in stirring up trouble in a non-strategic area like Maluku. Of course, "operations" that were not authorized by the armed forces commander, but were nonetheless lethal and well-organized, are another matter. Many incidents that involved soldiers "taking sides" looked as if they were at least tolerated, if not condoned, by commanding officers. Inasmuch as these actively partisan soldiers could depend on organizational support higher up the command chain, they demonstrated the dangerous state of disarray in which the armed forces now found themselves.

This is not to say the Maluku security apparatus did not do well out of Ambon. In March, and again in December 1999, the military temporarily took over control of security from the newly independent police force. In May 1999, Maluku was made a new military area command (kodam) - the first such reorganization in a decade and a half. The Maluku police, meanwhile, had their organizational status lifted from "type $C^{\prime \prime}$ to "type B" in November 1999 to enable them to cope with the crisis. Both developments meant more personnel and equipment, higher ranks, and more funding for the army and police. On June 27, 2000, martial law (technically a "civil emergency") was declared in the region under a 1959 law.

The declaration substantially increased military powers in the region. In addition to the "territorial" garrison troops normally stationed in Maluku under Indonesia's unique system of military control developed under Suharto's New Order, battalions of soldiers and marines from Sulawesi, Java, or elsewhere were now rotated through the trouble spots with bewildering speed.

The military solution was adopted after strong urging by local Ambon elites, perhaps especially, but not exclusively, the Muslim ones. It implied a serious reversal of the democratic progress that had been achieved elsewhere in Indonesia. Reviving a familiar theme from New Order discourse, top military officers almost seemed to derive satisfaction from giving vent to their exasperation with "society" for its immaturity.

Contrary to the military rhetoric promising quick answers, evidence on the ground pointed to a security apparatus in serious disarray. There were numerous instances of soldiers and police officers taking sides and shooting one another across the front line in Ambon city. In a pattern notoriously familiar to students of East Timor, it proved difficult to determine who held authority over the troops, since the new troops were not clearly under the jurisdiction of the local territorial command. As each unit came under public scrutiny for its failures, it would be replaced with another. Thus, these disruptive incidents surely resulted from the failure of a vastly overrated organization, indeed a failure of the state, rather than from a devious plan hatched in Jakarta to create unrest. When the Defense Minister confessed that the state budget only covered 25 percent of the military's "minimum operational costs," the rest being obtained through ad hoc efforts at every unit level, he was really confessing that the state had negligible control over the armed forces. Perhaps the very term "armed forces" was a fig leaf that covered a far less coherent reality. 
Another much-discussed Jakarta connection was political thugs (preman). That the link between high politics and street-level criminality is intimate and important in Jakarta and other big cities around Indonesia is well established. ${ }^{10}$ Maluku toughs were prominent in the Jakarta gang scene, where they engaged in protection rackets as well as political intimidation. Many Protestant Ambonese belonged to a gang with links to well-connected Pemuda Pancasila leader, Yorrys Raweyai, while Muslim Ambonese belonged to a breakaway faction of Pemuda Pancasila that began building links with fundamentalist Muslim organizations. Yorrys used to be close to the Suharto family, and his star fell with theirs. So when the Protestant Ambonese came out second best in a gangland turf war with religious overtones in Ketapang, inner Jakarta, on November 30,1998 , they had no place to go but home. The arrival of several hundred hooligans in Ambon city certainly helped raise tensions there.

However, something is wrong with our perspective if we think of these "outsider" thugs as the end of a tangled thread that, if we follow it to Jakarta, will help us make sense of the Maluku wars. This kind of analysis, which presumes the deployment of "outside agitators" by powers-that-be in Java, misrepresents the actual significance of the preman connections in Maluku, just as similar analyses have misrepresented the significance of other outsiders in the conflicts. In May and June 2000, a controversy arose over Islamic fighters (laskar jihad) from Java who were going to Ambon and North Maluku to help defend their brethren against the Protestants; at around the same time one heard allegations that separatist rebels (Republik Maluku Selatan, RMS) had come to Ambon from their exile in the Netherlands just as the fighting started. But the outsider preman-or the outside laskar, or outside separatist rebels-are unlikely to have been deployed by Java, if only because authorities in Java are not that well organized or committed to generating unrest in Maluku.

To understand the Maluku wars we must abandon the Jakarta-centric perspective and embrace the one thing that makes Maluku such an important, if depressing, case study for post-New Order Indonesia-its fundamentally local character. The sheer inability of anyone in Jakarta to come up with any constructive ideas on how to resolve the Maluku crisis throughout 1999 and 2000, other than to form yet another "team" to pester the locals with more inane questions, should have warned us that Jakarta was not the master key to understanding Maluku.

\section{State Failure}

The Maluku wars should first be seen as a massive failure of the state to provide security to its citizens. At the simplest level, the problem was a typical Third World lack of capacity, especially on the periphery. Ambon's police station had room for only twenty detainees; there was only one new and one very old fire engine and practically no hydrants for a city of 300,000 at the outbreak of fighting; the provincial disaster relief coordination service, tasked with simply counting victims, did not even have a motorcycle, let alone a motorcar.

10 Joshua Barker, "State of Fear: Controlling the Criminal Contagion in Suharto's New Order," Indonesia 66 (October 1998): 7-42; Loren Ryter, "Pemuda Pancasila: The Last Loyalist Free Men of Suharto's Order?" Indonesia 66 (October 1998): 45-73. 
10 Gerry van Klinken

There were plenty of civil servants in Ambon, yet their capacity fell woefully short when called on to deal with the insecurity created by the end of the New Order. The first deployment of troops led to more deaths by shooting than by rioting. Soon amateur video footage began to turn up of uniformed and fully armed soldiers and police fighting alongside the rioters. Probably they were locals under severe peer group pressure to help. The distinction between state and society became blurred as the security forces reproduced the factionalism within society. Locally raised sectarian money could have provided an important incentive for cash-strapped troops as well (questions about how the Maluku fighting was financed have not been sufficiently researched). Underfunded troops certainly did little to create confidence when, from the beginning, they began charging big sums to convey passengers to or from the airport and harbor. Meanwhile, they were seizing few of the firearms in use by rival militias. Nevertheless, they did often contain the Ambon fighting by imposing curfews and operating armed checkpoints at all major crossing points. Maj-Gen Suadi Marasabessy, in charge of the high-powered Team of 19, persuaded the center to commit large army, navy, and air force resources to patrol the area.

Politically, too, the government had few ideas beyond establishing numerous teams to talk with religious leaders, while lamenting the passing of the "traditional" reconciliation doctrines of pela gandong (in Ambon) and larvul ngabal (in Southeast Maluku). When both Abdurrahman Wahid and Megawati made it a priority to visit Ambon after they were elected as president and vice-president in October 1999, they came with empty hands, and Megawati soon after traveled to Hong Kong for a holiday.

\section{A Bottom-up View: Unemployed Youth}

Asked if they had expected this outburst, refugees I interviewed on both sides of the conflict in March 2000 (non-elite people, almost by definition) invariably said they were caught completely by surprise. Nor were the victims generally able to say what might have "caused" the violence. They said they could only tell what they sawangry men coming at their house with machetes.

A bottom-up view of the violence could profitably begin with those angry young men. As we shall see, there were a lot of young men in Ambon, whose one hope for material security in life lay in getting a job in the public service, and who knew that to get one they had to have the right connections. To approach the problem of communal violence from below, we therefore need to begin with some demographics, then move on to employment patterns, and then describe the way in which valuable goods-such as employment in the civil service-are exchanged across Maluku's social landscape. I will argue that they are exchanged not in meritocratic ways, but through patronage networks that take note of one's place of residence, religion, and social hierarchy. Such patronage networks lie at the heart of the Indonesian polity and explain its volatility at moments of regime change.

Urban Malukan society is extraordinarily young. Where contemporary industrial society has sometimes substantially less than 40 percent of its population under 
twenty-five years of age, and where Java comes in around 50 percent, that figure in Maluku stands at just under 60 percent, and locally can climb even higher. ${ }^{11}$

Many of these young people, moreover, were out of work. Data on unemployment, even before the economic crisis of 1998, are difficult to find and then difficult to interpret. But some statistics for urban Ambon suggest the figures were high. Benteng, for example, on the western outskirts of Ambon city, had 73.2 percent of the population listed as not (yet) employed in 1994. This high figure included children, of whom there were many ( 33 percent under the age of fifteen), but this still seems to amount to a great deal of unemployment. ${ }^{12}$

For those who were employed, these admittedly fragmentary statistics further suggest a high dependence on the civil service in Protestant Ambon city suburbs, whereas Muslim suburbs tend to depend on the private sector. In Benteng, for example, 71 percent of those who did work were in the public service. Before the violence broke out, Benteng was 71.5 percent Christian (52.7 percent Protestant, the remainder Catholic). By contrast, in the inner city suburb of Batumerah (75.7 percent Muslim), less than eight percent of the working population was employed in the public service, while 77.8 percent were either self-employed traders (pedagang) or in business (wiraswasta) -I have no figures on unemployment there. ${ }^{13}$ Civil service employment is secure, and most Indonesians regard it as desirable for that reason. But recruitment is notoriously corrupt, and this makes competition for such positions a volatile matter.

How did the economic crisis of 1998 have an impact on employment in Ambon? Data is sketchy. Unemployment is unlikely to have climbed as dramatically as it did in the construction and manufacturing sectors of big cities like Jakarta. However, civil service wages are low, and during the crisis they fell far behind the raging inflation of that year, thus no doubt creating a sense of anxiety in that sector. Certainly the destruction of the economy and of so many government offices once fighting had started greatly worsened unemployment and thus added a feedback loop that amplified anxiety on all sides.

If we roughly eliminate Maluku's rural working population by subtracting those employed in agriculture (which includes fisheries), then we can estimate the proportion of the urban work force employed in the civil service. In Maluku the figure for 1998 came to a high 21.6 percent-more than double the national average of 8.5 percent. ${ }^{14}$

\footnotetext{
${ }^{11}$ In Australia, the proportion of people under twenty-five years of age is 36.5 percent, in the US it is 35.7 percent, in Germany just $\mathbf{2 7 . 9}$ percent, as calculated by Lance Castles with data taken from United Nations Statistical Office, Demographic Yearbook (New York: United Nations, 1995). For Maluku province it is 58.1 percent, nearly the same in urban and rural areas. Compare East Java 48.8 percent, Bali 47.7 percent, and Jakarta 51.9 percent, calculated by Lance Castles with data taken from Penduduk Indonesia: Hasil Survei Penduduk antar Sensus 1995 (Supas, Jakarta: Biro Pusat Statistik, Seri S2, 1995).

12 Agustina Carolina Alfons, "Pembinaan pemuda putus sekolah dan pengaruhnya terhadap terciptanya keamanan dan ketertiban masyarakat di kelurahan Benteng kecamatan Nusaniwe kotamadya daerah tingkat II Ambon" (BA Thesis, Universitas Pattimura, Ambon, 1994), pp. 39, 45.

13 Abdul Rauf Latulumamina, “Konflik batas wilayah dan pengaruhnya terhadap pelaksanaan pembangunan di desa Batu Merah wilayah kecamatan Sirimau kotamadya daerah tingkat II Ambon" (BA Thesis, Universitas Pattimura, Ambon, 1996), pp. 40-41.

14 Statistik Indonesia 1998, Jakarta: Central Bureau of Statistics, 1998, tables 3.2.5 and 3.2.15. If in addition we were able to estimate the proportion of the formal private sector dependent on government contracts, we
} 
12 Gerry van Klinken

These statistics clearly need fleshing out. But they at least suggest that Ambon city had (a) a lot of young people, (b) many of whom were idle. Moreover, (c) those who did work were often employed as civil servants, especially (d) if they were Protestant, whereas Muslims tended to work in the private sector. The potential for conflict grew as energetic young Protestants and Muslims competed for limited work with the knowledge that the opportunities depended less on ability than on one's connections.

If one adds (e) the 1998 economic crisis, which may have imposed a bigger burden on civil-service dependent Protestants than private-sector dependent Muslims, then one senses the potential for considerable tension between young men of neighboring suburbs, and that tension would be of a religious nature. Both Benteng and Batumerah, each of which lies near suburbs with a different religious majority, saw much fighting in 1999.

\section{Religion, Place, and Hierarchy}

\section{Religion}

Religion and place are important in the lives of Maluku's inhabitants. They make it more difficult to establish a civil society in which citizenship is not conditional on either. We have already seen that the life chances for a young person in Ambon city are rather too dependent on whether they are born in a Protestant or a Muslim suburb. We now need to stress that being Protestant or Muslim is not merely a door to a career, but is a state that roots a person in an exclusive life world; viewed from inside that world, the other-either Protestant or Muslim-is perceived as an enemy.

The last reliable census data on religious affiliation in the regencies of Maluku is now three decades old. Later figures tell us that the proportion of Muslims in Maluku province as a whole has grown from 49.9 percent in 1971, through 54.8 percent in 1985 , to 56.8 percent in 1990.15 The Muslim segment has experienced more inmigration, as well as apparently a higher birth rate, while the Protestant segment may have experienced more out-migration. Thus, Muslims form a slight but growing majority throughout Maluku, while Protestants continue to make up a local majority in Ambon city and Southeast Maluku. Catholicism and traditional religion are insignificant everywhere except in Southeast Maluku. Maluku is one of the few regions in majority Muslim Indonesia where Christians do make up local majorities. Others can be found in Irian Jaya, East Nusa Tenggara, North Sulawesi, North Sumatra, and some parts of Kalimantan.

would obtain an even sharper picture of an urban society that needs the government more than do most urban societies around the country. The proportion of central disbursements in a province's Gross Regional Domestic Product indicates that province's dependence on government handouts and contracts, since these disbursements are largely used for infrastructure development. In Maluku they make up 19.4 percent of GRDP, more than twice the national average of 7.8 percent. See Colin Barlow and Joan Hardjono, eds., Indonesia Assessment 1995: Development in Eastern Indonesia (Canberra: RSPAS, ANU, 1996), p. 6.

15 Calculated by Lance Castles from Biro Pusat Statistik data. For 1971, see Sensus Penduduk 1971: Seri E (Jakarta: Biro Pusat Statistik, 1971). Number 25 concerns Maluku. 
Bloody Idul Fitri (January 19, 1999) opened the series of Maluku conflicts, and we have already noted the importance of the religious calendar at other key moments in the conflict. Millennialist fears may have played a role too, especially in Protestant circles. One Protestant minister, writing in the terrified atmosphere of the first four days of fighting in Ambon, said "the whole city of Ambon had been in an uproar" the previous January 15, when an image of Jesus weeping and carrying a lamb had appeared on the wall of a huge storm drain. "Thousands" gathered to watch. One man, also a minister, found he could not erase the image with a knife. "People say that every time an appearance like this occurs in Ambon something is bound to happen," the minister wrote. ${ }^{16}$ Locals told me there had been "many" such epiphanies in early 1999.

Apocalyptic fears infected Muslims as well. Like many Protestants, they interpreted the Maluku violence, once it started, as a sign of the end (kiamat). Their fears tended to focus on the date 9/9/99. One report says "20,000" fighting Muslim men gathered from Hitu and nearby villages in northern Ambon on that day to "come down from the mountain" and help Muslims in Ambon city face a great conflagration that was expected there. They were only turned back at the last moment by a show of police force. ${ }^{17}$

Most villages take pride in either a huge church or a similarly impressive mosque that forms its center-piece. Throughout the 1999 conflict, rumors that one's house of worship had been burned down, or that worshippers were massacred while at prayer, repeatedly inspired new violence. The massacre of hundreds of women and children in two village mosques near Galela, North Maluku, shortly after Christmas, later led to the laskar jihad movement from Java. Mosques and churches were the main target of massed attacks. The Al Fatah mosque and the Maranatha Protestant church in Ambon were also the headquarters of fighting forces on each side. Refugees were kept there deliberately, one Ambonese parliamentarian told me, to inspire anger in worshippers who observed them there in their misery each week.

Even in urban areas-not just rural ones-there are no significant voluntary social organizations outside the church or the mosque. A study of the 96 percent Protestant Ambon suburb of Hative Besar, just across the bay from the city center, found that the suburb's church leaders were on average older, better educated, and better paid than the local government leaders, whom they clearly regarded as their social inferiors. ${ }^{18}$ In his study of youth in Ternate, Christian Kiem underlined the importance to young lives

\footnotetext{
16 Anonymous, "Perang Ambon berkobar," Maluku-net@lava.net, February 26, 1999.

17 Harun Husein, "Pendekar Hitu dan mitos Kuda Putih," unpublished manuscript, undated (late 1999), apparently reportage for Gamma news weekly, p. 4. This contains a fascinating account of the miraculous events that inspired the jihad forces from Hitu in the north. Nils Bubandt has further important observations on millennialism in the Maluku wars. See "Malukan Apocalypse: Themes in the Dynamics of Violence in Eastern Indonesia," paper prepared for the workshop "Conflict and Violence in Indonesia," Humboldt Universität, Berlin, July 3-5, 2000.

18 Rinaldo Matauseja, "Masalah kerjasama antar elit desa dalam pembangunan masyarakat desa di desa Hative Besar kecematan Teluk Ambon Baguala kotamadya dati II Ambon" (BA Thesis, Universitas Pattimura, Ambon, 1995).
} 
of Islamic youth organizations. ${ }^{19}$ In Ambon at least, such strongly segregated youth socialization leaves its adherents with a sufficiently distinctive vocabulary, so that locals claim they can instantly identify someone's religion if they hear that person speak.

Near the Southeast Maluku town of Tual, P. M. Laksono described a "segmentation" into Christian and Muslim villages that is so complete that even the water wells are designated as Perigi Islam or Perigi Kristen. Although Catholics and Protestants lived in the same "Christian" village, they did so in separate areas within the village. Laksono concluded darkly that this was a deeply riven society, unable to resolve its differences through everyday dialogue. ${ }^{20}$

Maluku's religious map is the product of a long history in which politics and religion have been closely intertwined. State-funded missionaries sailed out on Portuguese warships in the sixteenth century, part of an imperial strategy to win the lucrative spice trade by means of arms and political manipulation. Not always reluctantly, Dutch Protestant missionaries continued the game of winning Asian hearts and minds for the tiny Netherlands by winning them for God.

From the early nineteenth century, the colonial administration paid more to recruit Protestant Ambonese men as soldiers than they did to recruit Javanese because the former were seen to have greater loyalty to the House of Orange. At first few were tempted, but when clove prices collapsed at the end of the century, so many accepted the offer to join not merely the army but also the corps of teachers and civil servants all over the Indies that Chauvel wrote of the emergence of a new "middle class" in Ambon. It was entirely Protestant. ${ }^{21}$

The colonial precursor of the Maluku Protestant Church (Gereja Protestant Maluku) was the state-run Indische Kerk. One indignant missionary wrote about it in 1927: "Its basic conception is totally un-Christian and un-Protestant [. . . ]. It is a government institution for spiritual care." 22 Ambonese soldiers had been sent in to fight Dutch colonial battles against other Indonesians so often that when Indonesia became independent they were afraid of retribution. In 1950, they led a South Maluku revolt against Jakarta. It failed. By the late Suharto era, powerful interests in Jakarta had increasingly come to regard not Protestants, but Muslims, as "loyal and dependable." In that sense, the Maluku wars of 1999-2000 can be seen as a muchdelayed reaction to the political changes since $1950 .{ }^{23}$

${ }^{19}$ Christian G. Kiem, Growing Up in Indonesia: Youth and Social Change in a Moluccan Town, (Saarbrucken/ Fort Lauderdale: Breitenbach, 1993), pp. 87-118.

20 P. M. Laksono, "Exchange and its Other: A Reflection on the Common Ground for the Keiese," pp. 156-76 in Remaking Maluku, ed. David Mearns and Chris Healey (Darwin: Northern Territory University Center for Southeast Asian Studies, 1996), p. 166.

21 Richard Chauvel, Nationalists, Soldiers and Separatists: The Ambonese Islands from Colonialism to Revolt (Leiden: KITLV Press, 1990).

22 Hendrik Kraemer, From Missionfield to Independent Church (The Hague: Boekencentrum, 1958), p. 33.

${ }^{23}$ Karel Steenbrink traces the Maluku conflict to both the exclusivist historical claims of the Islamic, Protestant, and Catholic communities, and to the manipulation of these religions by the anti-communist Suharto regime. See Karel Steenbrink, "Interpretations of Christian-Muslim Violence in the Moluccas," Studies in Interreligious Dialogue (Louvain, Peeters), no. 11 (2001): 1-28. 
Place

Religion is not the only cleavage within Maluku society that has been entrenched by a history of power politics. Places-the village or kampung-have remained autonomous to an extent that surprises visitors from Java. David Mearns has shown in a study on Ambon kampung that the transformation of place from a ritualized or sacred space to a commodified space, so often observed in urban contexts elsewhere, hardly seems to happen here. ${ }^{24}$ Origin myths and place magic remain potent and serve to separate "outsiders" from "insiders," and thus to nurture suspicions of the kind that exploded in the violence against Butonese outsiders in early 1999. "That even President Habibie can apparently have been fooled into believing that Ambon was an example of mutual tolerance for the rest of the nation prior to the outbreak of the terrible violence," Mearns concluded, "only adds to the tragedy."

Place, too, acquired much of its aura in colonial times. Village heads in this part of Maluku, to this day retaining the reverential title "kings" (raja negeri) in a terminology frozen since Dutch colonial times, can recount key dates in the administrative history of their "country" (negeri) going back a century and a half. Many tell stories with gusto about inter-villages battles that took place in the seventeenth century. Villages have supposedly traditional relations with specific other villages under a system known as pela gandong, which every Ambonese can explain. Most of Ambon's elites come from only a handful of villages.

The way place, religious community, and the patronage ties that flowed through them fed the fighting in Ambon became somewhat clearer to me when an Ambonese NGO activist, a young Muslim outraged by the bloodshed, showed me a map he had drawn. On it were marked the red and white militia posts (posko) situated near the front line as it snaked through Ambon city.

As one might expect, some were held by local men. However, most were occupied by men not from the city, but from famous "fighting" villages in the hinterland, either Protestant or Muslim. ${ }^{25}$ This map of a city at war showed that different localities in the city had robust identities as being either Protestant or Muslim. Moreover, these identities were constantly reinforced by ties of obligation to various respectively Protestant or Muslim villages in the hinterland. According to the terms of the clientelist bargain accepted by rural and urban co-religionists, rural men were expected to live up to a "tradition" of martial valor with a religious flavor, while their urban allies were expected to provide access to money and jobs. We shall see in a moment in what way this social landscape became the setting for the Ambonese violence.

\footnotetext{
${ }^{24}$ David Mearns, "Urban Kampongs in Ambon: Whose Domain? Whose Desa?" The Australian Journal of Anthropology 10,1 (April 19, 1999): 15-33.

${ }^{25}$ Two white posts were held by men from the ancient Muslim village confederation of Hatuhaha-Pelauw, Orij, Rohomoni, Kailolo, and Kabau-on Haruku Island, east of Ambon. Two more were held by Muslim warriors from the Leihitu region-Hitu, Mamala, Morela, Wakal, Hila, Kaitetu, Negri Lima and Asiluluon the north coast of Ambon Island. (We saw above how Hitu men came to help their brethren on 9/9/99.) Another was held by Sanana Island men. Most red posts-at least five-were held by men from Protestant villages on islands east of Ambon. On Saparua, which lies beyond Haruku, they came from Sirisori Sarani, Ulath, and Ouw. On Haruku they came from Sameth, Oma, and Aboru. Some came from Nusa Laut. These were not new connections. Kudamati, for example, a front-line Protestant suburb in the heart of Ambon city, had long been infamous for its Saparua thugs.
} 
16 Gerry van Klinken

Most of the "fighting" hinterland villages themselves have long memories of conflict with neighboring villages of the opposite religion. Land titles are one source of conflict-the system is still largely village-based and cannot readily handle non-local landowners. A case can be mounted for the argument that the Maluku conflict represents a resurgence of a "Malay" political pattern that predates the arrival of the centralized modern state, one characterized by many small centers of power with local bases. However, that would overlook the importance of the (weak) central state, which by its very weakness lends vehemence to irregular, clientelist forms of competition for control over its resources.

\section{Hierarchy}

The third type of cleavage is a closed social stratification system in many areas that separates a hereditary aristocracy from commoners. This seems to be important especially in areas away from Ambon. Among the Kei people who dominate Southeast Maluku, these social segments (Laksono refused to use the term "castes") are known as mel-mel (or orang kaya, sometimes but not quite appropriately known as the nobility), ren-ren (commoners), and iri-iri (slaves). In his study of intra-elite dynamics at the regional parliamentary assembly in Southeast Maluku, Jusuf Madubun noted the absolute dominance up to the present day of the ascriptive mel-mel segment within the formal institutions of power. ${ }^{26}$ Membership in the aristocracy is the first (but unwritten!) rule governing participation in the local governing elite. Unsurprisingly, patron-client relations rather than Weberian legal-rational relations dominate recruitment mechanisms that lead to positions of power within the local government. In "normal" times an outsider would hardly know that the bureaucratic rules are only a veil for a more personalized reality. But in the event of a serious breakdown in the patronage relations that go on behind the scenes, all pretense must be shed and rival networks transform themselves with alarming rapidity into war machines.

If Southeast Maluku knows a traditional aristocratic social segment, Ternate retains a sultan who perpetuates myths of divine sonship. Formally speaking, this sultan, like the other two or three Maluku sultans who survived centuries of colonialism, is acknowledged only as a "traditional chief" (ketua adat) without real powers. The sultans of Ternate, Tidore, and Bacan each signed away those powers to the Dutch in the first decade of the twentieth century, and they did not regain them upon independence. Indeed Van Fraassen, who later wrote the definitive history of Ternate, thought in 1984 that the institutions of the Ternatan sultanate "survive only in folklore, not as politically significant elements." 27 This makes the reemergence of the sultanates in 1999 all the more remarkable.

\footnotetext{
26 Jusuf Madubun, "Jaringan elite dan mekanisme perwakilan politik di tingkat lokal: Kasus DPRD kabupaten daerah tingkat II Maluku Tenggara" (MA Thesis, Universitas Gadjah Mada, Program Pasca Sarjana, Yogyakarta, 1997), p. 55.

27 Quoted in Kiem, Growing Up in Indonesia, p. 93.
} 


\section{Local Elites and Their Interests}

Thus far, we have sketched the social landscape in which competition for scarce state resources is likely to break out of its fragile institutional bounds. Seen from below, it is a landscape of entrenched inequality and intolerance. These characteristics will certainly influence the post-conflict, reconciliation phase of the Maluku wars, and insights into the complex situation will be essential to guide that phase. ${ }^{28}$ But at this point it is important to resist the temptation to close the discussion by concluding that society in Maluku is deeply dysfunctional and anomic. Such a conclusion serves the interests of those who prefer not to consider questions of power.

No explanation that ignores agency can do justice to the victims of this war. We have in any case not yet explained why the violence had to happen at this precise moment. It will be more fruitful to see the Maluku conflict in terms of an interaction between the long-standing "primordialist" social relations we have sketched aboveparticularly the large number of urban youth looking for work and the inescapable web of family, village, and religious patrons that provides their only avenue of getting itand the more immediate "instrumentalist" concerns of local elites who engaged in political struggle at the interface between that society and the state. The suddenness with which communal fighting broke out just as elections were around the corner, in a province that had known nothing like this before, made it look suspiciously like an elite affair. In that case, societal demands for a moral accounting sound quite reasonable.

Unlike the refugees, who offered no explanation beyond the terrifying image of men with machetes, the nation's elites were quick to accuse certain agents of triggering and then intensifying the Maluku violence. Nearly all explanations that filled the newspapers invoked the provokator. It was not unreasonable to suspect the involvement of "outside agitators," as there have been times in modern Indonesian history where powerful actors, including state actors, have used provocateurs. The trouble was, as a common saying had it, that the provokator is "like the wind-you can feel their effect but you can never grasp them." Allegations naming the provokator had, over the two years since Suharto's resignation, become part of the competitive game the nation's rival elites played against each other. Student activists blamed the military, Muslims blamed Protestant "separatists," Protestants and "cultural" Muslims blamed "political" Muslim "fanatics," and everyone blamed Suharto and his cronies. Any serious analyst found it difficult to take this collection of factless and contextless intrigues seriously. A lack of hard evidence did not rule out their presence, but made them analytically problematic. Talk of the provokator reflected a mind-set in which order was constantly imperiled by disorder, but mysteriously, without involving social forces.

Yet, the deeply held popular conviction that elites have followers who are likely to clash with other followers - what scholars call "clientelism" - was an important insight not always appreciated by foreign observers. Clientelism is an instrumentalist tool that

${ }^{28}$ Other important anthropological studies of the conflict include those by Dieter Bartels on the decline of the socially integrating pela gandong custom, and Nils Bubandt on the apocalypticism of the Maluku violence. See Dieter Bartels, "Your God is No Longer Mine: Moslem-Christian Fratricide in the Central Moluccas (Indonesia) after a Half-Millennium of Tolerant Co-existence and Ethnic Unity," Indonesia-L July 27, 2000; Nils Bubandt, "Malukan apocalypse." 
lays the burden of moral responsibility for the violence at the feet of elites within an unequal society.

A local perspective on the Maluku wars quickly leads us to the main problem elites there face-how to control the bureaucracy for their personal gain. We have already glimpsed how important the civil service is to the provincial economy. If in Java it is perhaps possible to get rich without being close to the bureaucracy, the same is not true in Maluku.

Endemic corruption furthermore elevates unwritten rules far above written ones and makes this a dangerous arena. Corruption and authoritarianism are part of a clientelist system in which elites that represent no one but themselves fight behind the scenes for the spoils of office. In Maluku, perhaps more than anywhere else, religion has long been the most important identity marker of the various clientelist networks. The Protestant Dutch belief that Christianity made the natives "loyal" created an Ambonese Protestant culture entirely dependent on the government. In the 1990s, a rival Muslim network began to emerge that offered access to government patronage also for Muslim Ambonese, as well as for non-Ambonese Muslim migrants.

\section{Ambon}

Complaints common among ordinary Ambonese Protestants that Muslims were about to push them out of the civil service, and complaints equally common among ordinary Ambonese Muslims that Protestants were defensive of their privileges in this regard, showed that the average Ambonese was well aware that this war was about patronage, not about the correct way to worship God. In October 1998, an anonymous pamphlet appeared in Ambon. One of many, this one caused more of a stir than most. It alleged (to my knowledge without any factual basis) that the governor of Maluku planned to replace "all thirty-eight" top civil servants with Muslims. ${ }^{29}$ In March 1999, the governor acknowledged that the allegation in this pamphlet was one of two triggers for the bloody Ambon conflict, the other being resentment against "outsiders" for dominating the market place. ${ }^{30}$

In fact, the big challenge to Protestant dominance of the top levels of Maluku's civil service had come not from Saleh Latuconsina, but from his predecessor (and distant relative), Akib Latuconsina (1992-97). He was the first Muslim Ambonese to win the top provincial job, and the first Ambonese to hold that position since $G$. J. Latutumahina stepped down in 1968. Akib's appointment coincided with a new readiness on the part of President Suharto, who felt under pressure from the armed forces, to play the religious card. Suharto had formed the Indonesian Muslim Intellectuals Association (ICMI) a couple of years earlier, and observers described it as a new patronage organization. It drew on a new generation of educated Islamic

29 "Dari Ketapang ke Ambon?" Tekad, January 25-31, 1999; "Pemda Maluku bantah pernyataan Gus Dur soal kerusuhan Ambon," Gatra, January 27, 1999, “Mengenali jejak sang provokator,” Tajuk, March 4-17, 1999.

30 "Drs Ir Saleh Latuconsina, Gubernur Maluku: Sekarang sudah Terjadi SARA," Untmat, March 15, 1999. 
activists. ${ }^{31}$ Akib Latuconsina was its Maluku and Ambon branch chair. The subsequent overhaul saw top bureaucrats with Christian names make room for Muslim ones. Saleh Latuconsina continued the trend by favoring graduates who came from the Haruku Island villages of Ori, Pelauw (his own village), and Kailolo-abbreviated "Opek." Curiously, no one dared to challenge the assertion that this decision was based on religion and was not a show of favoritism to the patrons' own family or village. These were the same villages, we note, whose men were so prominent on the Muslim front line in 1999.

One credible Indonesian source presented some recent data on the religious distribution within Maluku's bureaucracy. ${ }^{32}$ The "thirty-eight" top provincial officials mentioned in the pamphlet fall in salary categories IVB (lowest) to IVE (highest). Of these, 74 percent were Muslim. This was a little higher than the proportion of Muslims in the provincial population. Further down the bureaucratic ladder, where most of the jobs are, the percentage of Muslims declined to half, or somewhat less than the proportion of Muslims within Maluku's population.

How might this transformation of the top levels of the bureaucracy have influenced the 1999 violence? One early explanation blamed Protestants, who wanted to restore by violent means the influence they had lost to the gradual Islamization in Jakarta. A military intelligence document dated April 1999 alleged that the key event was the election of a new Maluku governor in October 1997.33 Akib's chief rival in 1992 had been Freddy Latumahina, a Golkar national parliamentarian and senior party functionary, and a Protestant. In 1997, Latumahina, now even more senior in the Golkar hierarchy, tried but failed again to win the governor's post. The military had not supported him.

Saleh Latuconsina, the governor of Maluku province throughout the conflict, was by no means fanatically religious. He had a technical doctorate from Marseilles. But personal religiosity is of no account in these matters. When he appointed a nonProtestant deputy governor and a non-Protestant provincial secretary (both were Catholics), the Protestant elite felt frozen out of the three most powerful jobs. The army document then speculated that Latumahina or those around him made their move by getting in touch with the criminal underworld, the key contact person being retired army colonel Dicky Wattimena, an Ambonese Protestant who had been (an apparently popular) mayor of Ambon in 1983-88, and before that commander of Suharto's presidential guard.

It is certainly true that the Ambonese Protestant gang leader mentioned in this army document, Berthy "Coker" Loupatty (as well as Berthy's brother, colleague, and sometimes rival, Agus Wattimena) went on to become prominent fighters on the Protestant side of the front line in Ambon city at Kudamati.

The "Protestants strike back" scenario has merit, but Freddy Latumahina, ambitious for the governorship, was not an entirely convincing bad guy. His defeat

31 Described in John T. Sidel, "Macet Total: Logics of Circulation and Accumulation in the Demise of Indonesia's New Order," Indonesia 66 (October 1998): 159-94.

32 S. Sinansari ecip, Menyulut Ambon-Kronologi Merambatnya Berbagai Kerusuhan Lintas Wilayah di Indonesia (Bandung: Mizan, November 1999), pp. 69-70.

33 "Jaringan Provokator Kerusuhan Ambon," Tajuk, April 15-28, 1999. 
took place a year before violence broke out. Moreover, Latumahina was a social climber who lived in Jakarta and did not enjoy great popularity in Ambon.

Much more likely as a trigger for the fighting in Ambon, glaringly obvious yet surprisingly under-reported, was the election that fell in the middle of the year. This open-ended event brought together all the elements we have discussed thus far into a volatile mix-numerous unemployed young men who socialized along religious lines, local elites who felt this election could make or break them, and personalized, weakly institutionalized links between the elites and those dependent young men. In this scenario, blame is not apportioned solely to one side or the other, but rather to elites on both sides who, in the absence of more civil modes of competition, resorted to religious mobilization.

Ambon was throughout the New Order a Golkar preserve, consistently turning up Golkar votes comparable to the national average of around 70 percent. Such results could only have been achieved with the collaboration of local elites. But Suharto's sudden resignation in May 1998 threw Golkar into such disarray that internal predictions soon had it losing the next election.

Unease had already begun to infect the nation's elites from late 1995 onwards, as evidenced by a series of explosive corruption allegations clearly fueled by cabinet-level leaks. As had happened during the previous period of major elite circulation in 19651966, inter-communal fighting began to break out in various places from late 1996. After May 1998, established elites at both the national and provincial level had little reason to believe that the old deals struck under Suharto would survive. They began to weigh up the potential of the alternative political parties to secure their access to power. Many of these parties were new, time was short, and the stakes were high. The initiative lay with those who dared.

Early in December 1998, the date for the election was officially set at June 7, 1999. At the same time parliament began debating the new electoral laws, which had been circulating in draft form since the previous August. Electoral preparations were thus just getting into full swing when the violence broke out in Ambon in mid-January. The colored strips of cloth the fighting men tied around their foreheads or arms from the very beginning were more reminiscent of party colors than of the religions. Protestants at first wore red-and-white, and in some places red or black $t$-shirts, and later exclusively red. Muslims at first wore green or white, and soon exclusively white. Red, red-and-white, and red-and-black were the colors of Megawati's secular PDI-P (Partai Demokrasi Indonesia-Perjuangan, or Indonesian Democracy Party-of Struggle), while green was the color used by most Islamic parties, including PPP (Partai Persatuan Pembangunan, or United Development Party) and PBB (Partai Bulan Bintang, or Crescent and Star Party). ${ }^{34}$ The color white was associated with Middle Eastern Islam.

The fighting men from Kudamati and Mardika on the Protestant side, or from Batumerah and Galunggung on the Muslim side, could well have been the same young men that the parties relied on to spread their message ahead of the election. Several prominent figures among the militants were political party leaders.

34 "Tourists Fearful amid Sectarian Violence," The Australian, January 22, 1999; Human Rights Watch Asia, "The Violence in Ambon," for January 19. 
On the Protestant side, the army document quoted above mentioned that Dicky Wattimena, the former Suharto palace guard commander and former Ambon mayor, was a PDI-P activist close to Elias Soplely, Ambon's PDI-P secretary, as well as to the fighting men Berthy "Coker" Loupatty and Agus Wattimena. ${ }^{35}$ A PDI-P activist flagged in one report as possibly active on the front line was M. J. ("Yoppie") Papilaya, parliamentarian and PDI-P branch chair for Ambon. ${ }^{36}$ While acknowledging these were "tentative suspicions" rather than allegations, the same report also named a Golkar delegate in the Suharto-era provincial assembly who was supposedly involved in purchasing guns for Protestants-Yosias ("Yossy") Polnaya, a relative of Berthy Loupatty and Agus Wattimena. All these political figures vehemently denied involvement.

On the Muslim side, the influential coordinating committee at the central Al Fatah mosque in Ambon city (Posko Umat Al Fatah) was headed by Ustadz (preacher) Ali Fauzi. This man was local chair of the radical Islamic "Moon and Star Party" (PBB), and well known for an interest in Islamic politics going back to the 1950s. His secretary was Yusuf Ely, a businessman and local chair of the Golkar spin-off party MKGR. Yusuf Ely's brother, Thamrin Ely, another significant spokesperson for Muslim interests, was the chair of PAN (Partai Amanat Nasional, or National Mandate Party) for Ambon. Another figure said to be influential among the fighters was Abdullah Tuasikal, a young businessman who spent time in Java (his brother lived in Yogyakarta) helping to organize a series of Islamic solidarity rallies (tabligh akbar), which were held in March 1999 and again in January 2000 by groups close to several radical Islamic parties, especially PBB.

These tantalizing glimpses demand more research. What this enumeration of names amounts to, I suggest, is a group of influential urban individuals who moved easily between business, party political, and religious circles, who were aware that party politics were now the way to bureaucratic power, and who knew that religion could provide them with the manpower they needed to make an impact. However, just how they conducted their campaigns, and to what extent they either egged on their supporters to acts of violence or rather were dragged into the maelstrom by those followers remains less than clear.

The fighting in Tual that began at the end of March was even more clearly the result of competition for bureaucratic office. Here, not the provincial government, but the regional (level II) government, was at stake. It pitted supporters of the Muslim regent against those of the Protestant regional secretary. Protestants accused the regent of backing Muslims, while Muslims accused the regional secretary (sekwilda) of backing Protestant Christians, each side urging the other's champion to resign. Tual town was about to have its status raised to that of "administrative city" (kota administratif), and voters in the June 7 election would also be electing the town's first municipal assembly (DPRD-II). ${ }^{37}$ Some media reports linked the fighting to local pre-election jostling.

\footnotetext{
35 Dicky Wattimena refused me an interview in March 2000.

36 Kontras and Lerai, Setahun Maluku Berdarah: Laporan Investigasi Januari 1999-Januari 2000 (Jakarta: Kontras \& Lerai, March 2000).

37 "Meraih kursi dari para pengungsi," Tajuk 2,6, early June 1999.
} 
22 Gerry van Klinken

The connection between party politics and the Ambon violence became even more obvious in July 1999. That the campaign period and election day itself went off with little further violence suggests a degree of elite control-perhaps an agreement to suspend conflict and play by the rules. PDI-P chair Megawati addressed a peaceful rally of twenty-five thousand on June 1. After long delays in counting, the Jakarta government finally announced the election results on July 21 . In one sense, the result for Ambon city looked remarkably New Order. The three New Order parties, Golkar, PDI(-P), and PPP, between them, sewed up 86 percent of the votes. The remaining votes were spread rather evenly between all the other forty-five competing parties. The most successful of these others was the PBB. It won just 2,438 votes-less than 2 percent of the total.

But the collapse of Golkar-it won only 19 percent of the national vote, and the same percentage in Ambon-made this election something new. The PDI-P had for long run neck-and-neck with the Islamic party, PPP, in the competition to see which was the smallest party in Ambon. Now it had won outright victory: 53 percent of the Ambon vote, leaving PPP with just 14 percent. PDI-P was clearly Ambon's new establishment party. The small parties had much reason to be disappointed, as did the Islamic parties generally. Partai Keadilan had worked hard in Maluku and had announced a wildly optimistic "target" of 40 percent of the vote there-it won only 1 percent. All the Islamic parties together won only 21 percent of Ambon's vote, just half what they might have won if all Muslims had voted Islamic. In any case, many Muslim voters had been disenfranchised by the violence. Some Ambonese observers told me they believed the exodus of tens of thousands of Muslim Butonese early in the conflict had been less a consequence of "ancient hatreds" than a practical ploy to remove a solid block of PPP voters. Indeed, Protestant leaders had been especially loud in their refusal to countenance the return of these Butonese just before the election.

The parties then went on to appoint delegates to the national, provincial, and municipal assemblies. All but one of PDI-P's delegates (someone in the municipal assembly) were Protestants. ${ }^{38}$ This identification of Protestantism with the PDI-P is surprising because there is no such association nationally. But the key lies in history. The PDI-P sprang from the PDI, which was formed in 1973 out of a fusion of Sukarnoera parties, and, since its inception, the PDI in Ambon had been largely dominated, and defined, by its Protestant "component," Parkindo, one of those earlier parties. ${ }^{39}$ So long as Golkar pulled off one overwhelming victory after another, Ambon's elites found it expedient to play by its secular rules, and Protestant versus Islamic rivalry in Ambon remained muted. But the 1998-99 collapse of Golkar transformed the political stage from an at least superficially "modernist" one back to the volatile pattern of religiously based politics evident in the 1955 election. In that election, the freest one before the 1999 event, Parkindo had stormed home with 49.36 percent of the vote, more than twice the tally of its nearest rival in the multiparty field, the Islamic party

38 Confirmed to me by PDI-P Maluku chairman, John Mailoa, in an interview March 24, 2000.

${ }^{39}$ Tatuhey Jusuf Idrus, "Studi Tentang Kemerosotan Perolehan suara PDI Dalam Pemilihan Umum 19711987 di Kotamadya Ambon"(MA Thesis, Universitas Gadjah Mada, Yogyakarta, 1990). 
Masyumi (24.10 percent). The secular party PNI (Partai Nasional Indonesia) came in a poor third with only 7.89 percent. ${ }^{40}$

The Second Riot may well have been triggered by the shock political elites in Ambon experienced when they realized the depth of this transformation. On the evening of July 23, assailants allegedly belonging to one or more rival parties threw rocks on the house of PDI-P Maluku chairperson, John Mailoa. Mailoa had invited other party leaders to join PDI-P in a commemoration of the July 27, 1996 militarybacked invasion of PDI's headquarters in Jakarta. Having just suffered a crushing defeat at the hands of John Mailoa, those other party leaders conceivably interpreted his gesture as an insensitive invitation to help celebrate the PDI-P victory. From here, conflict spread to the nearby middle-class university suburb of Poka, and then back to the front line in the city, where the death toll soon mounted alarmingly.

If the explanation focusing on party political elites and their dependents is correct, we would predict a new modus vivendi to emerge after the elections and hence for calm to return, albeit slowly. Unfortunately, it did not happen so quickly. Ambon suffered another outbreak just after Christmas 1999, which lacked a discernible political "reason." Serious street fighting across the usual front line in the city left another fifty or so dead in late June 2000. The latter event followed the arrival of thousands of Islamic fighters from Java (laskar jihad), who thus tipped the military balance sufficiently for the Muslim side to attempt a renewed (but once more largely futile) push for territory. But by September 2000, reports indicated the laskar jihad were being marginalized in Ambon.

An instrumentalist view of the Maluku wars takes the elite rhetoric on both sides of the conflict with more than a grain of salt. Elite Protestant opinion makers made much of the idea that theirs represented the authentic voice of the tolerant and indigenous Ambonese tradition of pela gandong, and that the conflict should be traced to an irruption of radical Islam, of what the New Order used to call the subversive, antiPancasila "extreme right." 41

Elite Muslim opinion makers also invoked themes likely to gain a sympathetic ear in Jakarta. They loudly proclaimed that Protestants were as "separatist" now as they had been during the RMS revolt of 1950, indeed that this was another Protestant (Kristen) RMS revolt. ${ }^{42}$ Islam represented the soul of Ambon, not a Christianity that had slipped in under the cover of foreign imperialism.

\footnotetext{
40 Election data for 1955 drawn from Alfian, Hasil Pemilu 1955 (Jakarta: Leknas-LIPI, 1973). Unfortunately the Alfian data set is slightly distorted because it excludes Nahdatul Ulama, which in 1971 won 5.93 percent of the vote.

41 The clearest example I have is John A. Titaley, "Kasus Ambon Dalam Perspektif Pertentangan Ideologis Indonesia," unpublished paper presented at Sarasehan Maluku, Salatiga, September 18, 1999. Rev. John Titaley is the brother of Maluku Protestant Church (GPM) synod chairman Rev. Sammy Titaley, and was at the time a PDI-P candidate for the nation's supreme law-making body, MPR. His analysis was echoed by other Protestants and Catholics. An official Protestant and Catholic legal team blamed the violence on "separatists who want to Islamicise Maluku." See Tim Pengacara Gereja (coordinated by Semmy Waileruni), "Himbauan kepada umat Islam di luar Maluku," Ambon, October 22, 1999.

42 M. Husni Putuhena, Buku putih Tragedi Kemanusiaan dalam Kerusuhan di Maluku-Sebuah Prosesi ulang Sejarah Masa lalu (Ambon: Lembaga Eksistensi Muslim Maluku [LEMM], October 1999); Rustam Kastor,
} 


\section{Gerry van Klinken}

Neither the Protestant nor the Muslim elite arguments held much water. Most Muslims I met in Ambon in March 2000, far from being on a crusade, seemed anxious to extract themselves in conciliatory ways from the small enclaves in which the war had trapped them. Nor were insistent Muslim claims that the military had discovered RMS weapon caches, flags, and training camps, ever supported by convincing proof. Such allegations had all the hallmarks of routine New Order military labeling of environmental and social justice protesters as subversive, hence "RMS." It is true that a remnant RMS organization exists in the Netherlands and was probably sending financial aid to Protestant relatives in Maluku. It is true too that many Protestant Ambonese grew more disillusioned with Jakarta than were their Muslim counterparts as the conflict wore on. But I have seen no credible evidence for an organized Protestant separatist movement within Maluku in 1999. This is not to say that separatism could not become an attractive option once the tide of war began to turn against the Protestants. In December 2000 Semmy Waileruny, one of the most vocal Protestant spokespersons throughout the conflict, lent his support to a declaration of support for RMS. 43

Propagandists on both sides made liberal use of history. The Muslim Husni Putuhena quoted the Western historian, C. R. Boxer, to show that Portuguese missionaries had been engaging in violent Christianization campaigns against Muslims since the Hitu War of 1520-1605.44 The Protestant John Titaley was keen to remind his listeners that Muslims had tried (but been prevented by Christians from eastern Indonesia) to impose Islam on the constitution in 1945, and that they had not given up even now. The Protestant raja of Porto in Saparua told me it would take "hundreds of years" for Protestants to reconcile with Muslims, because "everyone still remembered" Muslim treachery during the Iha War of 1632-1651.

\section{North Maluku}

If the argument that provincial elites should largely be held responsible for the Ambon violence is somewhat circumstantial, one can make a more direct argument in the case of North Maluku. There, as we have already seen in the summary account above, all reports on the violence used the language of clientelism. They spoke of sultans, regents, district heads, and their "traditional allies" at village level. However, as in Ambon further south, the bitterness of the fighting later probably severely weakened the authority links between the elites in Ternate and Tidore and their nominal dependents in the villages of nearby Halmahera.

One of the most remarkable aspects of the Maluku wars was the reemergence of two sultanates that throughout the New Order had been politically moribund. The sultan of Ternate had been active during the 1950s promoting autonomy for North Maluku, though with little success. His son, the current sultan, spent most of his life in Jakarta and was a Golkar functionary. He was the speaker of the local elected

Konspirasi Politik RMS dan Kristen; Tim Penyusun al-Mukmin, Tragedi Ambon (Jakarta: Yayasan alMukmin, April 1999).

43 "Basudara Muslim mendukung RMS," Siwalima, December 30, 2000.

44 Putuhena, Buku putih, pp. 8-10. 
assembly. His historic rival in the sultanate of Tidore just south of Ternate was even less empowered. That sultanate was empty for about a decade, one of many around the country that had lost all relevance except perhaps as a source of tourist revenue.

However, as the new province was announced, North Malukan elites fell into a competitive pattern that settled on the two centers most likely to have mobilizational appeal, namely the long-dormant Tidore and Ternate sultanates. Each could call on a large number of "traditional guards" (pasukan adat) drawn from communities with allegedly traditional loyalties to that house. In the case of Ternate, that included most of the Protestant Christians, who lived in the northern part of Halmahera. The Ternate sultan spoke often of traditional values that ran deeper than religion. Physical conflict began with a border dispute in the Kao district of Halmahera, but by the end of December there was fighting in the streets of Ternate itself, which left the Ternate sultanate severely weakened.

\section{The Future}

The "communal contenders" model of the Maluku wars implies that any resolution of the conflict must be sought within the framework of a common Indonesian state. This means that ways must be found (a) to democratize that state, especially at the local level, thereby depriving war-mongering elites of their legitimacy, and (b) to make the state effective for all its citizens, especially by providing a sense of security. This two-part recipe is commonly prescribed in similar situations elsewhere. ${ }^{45}$

Indonesia's unstable clientelistic state-society relations must move towards more democratic ones. Olle Törnquist has written a stimulating, agenda-setting paper along these lines, focusing on political parties and drawing on the ideas of Nicos Mouzelis and Sidney Tarrow. ${ }^{46}$ Most political and religious organizations in Maluku are complicit in the fighting, but there are several groups, mostly of young people, who do want to carry this agenda forward and who should be crucial in the post-conflict phase.

Making the state effective at the local level for all citizens will mean depoliticizing the police and armed forces, paying them exclusively through the state budget, strengthening the independence of the courts, and making recruitment procedures to the bureaucracy transparent, to name just the four most urgent needs out of a wellknown litany of needs. Without such reforms, it will be impossible to restore a sense of security and eliminate the communal militias.

\footnotetext{
45 For example, see the article by Scarritt, "Communal Conflict and Contention for Power," in Gurr, Minorities at Risk, dealing with sub-Saharan Africa.

46 Olle Törnquist, "Dynamics of Indonesian Democratisation," Third World Quarterly 21 (2000): 383-423.
} 
26 Gerry van Klinken

Clearly, this two-part agenda represents a long-term project, and it may not succeed. But there is no viable alternative, and it demands the support of the international community. ${ }^{47}$

${ }^{47}$ Fred Riggs uses the term "strategic democratisation" to challenge the international community to care as so many post-colonial "quasi-states" face internal disintegration along communal lines ("Turmoil among Nations, a Conceptual Essay: Ethnonationalism, Authoritarianism, Anarchy and Democracy,"

http:/ /www2.hawaii.edu/ fredr/6-tan2f.htm, a paper prepared for the International Studies Association Conference in Chicago, 22-25 February 1995. 